AGRICULTURE AND BIOLOGY JOURNAL OF NORTH AMERICA

ISSN Print: 2151-7517, ISSN Online: 2151-7525, doi:10.5251/abjna.2013.4.2.97.102

(C) 2013, ScienceHuß, http://www.scihub.org/ABJNA

\title{
Improving smallholder farming and extension in Nigeria: the Sasakawa Africa fund for extension education strategy
}

\author{
${ }^{1}$ Donye, A. O., ' Ja'afar-Furo, M. R. and ${ }^{2}$ Obinne, C. P. O. \\ ${ }^{1}$ Department of Agricultural Economics and Extension, \\ Adamawa State University, Mubi, Nigeria \\ ${ }^{2}$ Department of Agricultural Extension and Communication, \\ University of Agriculture, Makurdi, Nigeria
}

\begin{abstract}
The paper discusses the strategies used by the Sasakawa Africa Fund for Extension Education (SAFE) programme for improving smallholder farming and extension in Nigeria. The overall objective of the programme is to train mid-career extension staff to become university graduates of agricultural extension and innovations who are trained in various technical and leadership skills. The strategy to achieve this is based on the philosophy of the need to re-train mid-career agricultural extension workers that possess a great wealth of experience in field work in order to keep them abreast with recent agricultural innovations. The programme aims to acquaint the trainees with knowledge of recent scientific innovations and improved practices which have emerged over time so that the graduates can teach same to smallholder farmers. The needs assessment carried out before the establishment of the programme revealed the areas where mid-career extension workers need to be trained. These include, among others, value addition on agricultural commodities, storage and postharvest technology, irrigation farming and marketing of agricultural commodities as well as communication skills. Experiences observed in running the programmed reveal, inter alia, that the organizations where the trainees work did not live up to the agreement to sponsor their staff. Based on the problems, it is recommended, among others, that: (i). The universities running SAFE programme should design the training to give opportunity for part-time instead of only full-time programme, (ii).Agricultural organizations should release their mid-career extension workers to undergo the SAFE training programme.
\end{abstract}

Key words: Improving, smallholder, farming, extension, Nigeria.

\section{INTRODUCTION}

Smallholder farmers in developing countries have, for quite some decades, been carrying out their agricultural activities at subsistence levels. This is obvious because their farming operations are mostly characterized by traditional practices. The World Bank (1996) reported that low productivity in agriculture is the cause of high incidence of poverty in Nigeria. However, Njokuet al. (2007) and Ekong (2003) argued that, apart from agriculture, rural dwellers need to expand and diversify their sources of income and livelihood activities in order to reduce poverty. One of the major ways that smallholder farmers can achieve this is the adoption of affordable agricultural innovations that cut across the various facets of agriculture and agriculture-related enterprises.
The Government of Nigeria has been making concerted efforts along with other national and international non-governmental organizations to augment agricultural production and productivity of the nation's citizens. In order to achieve this national goal, various intervention initiatives and projects had been implemented at different periods by successive regimes. Most of such projects and programmes came with various packages of agricultural innovations and approaches. One of such programmes which were recently established by an international foundation is the Sasakawa Africa Fund for Extension Education (SAFE). The programme is presently being run in four Nigerian Universities. The Universities are:Ahmadu Bello University, Zaria in 2002, Bayero University, Kano in 2007, University of Ilorin in 2011 and Adamawa State University (ADSU), Mubi in 2011. It was established in ADSU, Mubi in order to accommodate interested beneficiaries within 
the north-east region of Nigeria and other bordering nations. The SAFE programme has been approved by Nigeria's university policy agency, Nigerian Universities Commission (NUC).

The overall objective of the SAFE programme in ADSU, Mubi is to produce university graduates of agricultural extension who are trained in various leadership and technical skills. The programme is specifically aimed at building the capacity of midcareer extension staff. It is, also, aimed at continually developing and implementing a curriculum that is demand-driven for the production of skilled extension staff for the improvement of rural community through their involvement in Animal and Crop Production, Postharvest Technology and Irrigation Agronomy as well as communication skills. After receiving the full training, the graduates are expected to return to their respective organizations and farming communities with a view to imparting the learnt innovative practices to smallholder farmers. Therefore, the thrust of this paper is to discuss the Adamawa State experience as it affects the role of innovation systems in smallholder farming.

\section{Needs Assessment for SAFE Curriculum} Development: It was observed by experts in agriculture and agricultural extension professionals that many years were spent in which emphasis was laid on giving farmers advice on agricultural production aspects e.g. crop production, animal production, fish production, etc. Little attention was given to other vital issues activities that could make remarkable changes in farmers' agricultural activities e.g.innovative storage practices/technologies, processing and use of processing machines, marketing of produce and commodities, etc. Thus, it became imperative that a shift be made to theseinnovations in order to balance farmers' agricultural activitiesfor greater output and outcome. In many instances too, the top-bottom approach to problems and needs identification and determination of objectives have been used by governments, programme administrators and agricultural experts in taking decisions on behalf of farmers in Nigeria. This mode of approach to agricultural key issues does not always auger well for beneficiaries of agricultural and rural development programmes. This is because needs are, in most cases, people-specific, locationspecific and sometimes time-specific. In other words, the needs of the people of a particular community, location and the time such needs arisemay be peculiar to them and not to those of other places. One unique philosophy behind the establishment of the SAFE programme is the need to re-train field agricultural extension workers who had left college many years earlier. This is important because new scientific innovations have emerged over time and the field workers need to be able to teach the improved practices.Considering these issues as those that can improve, enhance and facilitate the entire agricultural activities embarked upon by farmers when taken into cognizance at the planning stage, it has become expedient that the bottom-up approach be preferred and employed as a better way out.Therefore, before arriving at the courses that were reflected in the Adamawa State SAFE Programme Curriculum, a needs assessment was carried out in the north-east region of Nigeria. The region comprises six states namely, Adamawa, Bauchi, Borno, Gombe, Taraba and Yobe. Thereafter, a curriculum development workshop was organized and was later followed by a curriculum validation workshop in which experts and representatives of all the stakeholders participated.

Ja'afar-Furo et al. (2012) reported the results of the needs assessmentof ministries of agriculture and agriculture-related organizations presented a table showing the distribution of the organizations involved by their respective areas of needs for mid-career extension staff training in the north-east region of the nation as shown in Table 1.

Table 1:Distribution of Organizations Based on Needs for Mid-career Training ( $N=50)$

\begin{tabular}{lcc}
\hline Area of Needs for Training & Frequency & $\%$ of Organizations \\
\hline Livestock production and disease control & 35 & 70.00 \\
Storage and postharvest technology & 45 & 90.00 \\
Marketing of agricultural commodities & 48 & 96.00 \\
Irrigation farming & 25 & 50.00 \\
Value addition on agricultural commodities & 39 & 78.00 \\
Information and communication technology in agriculture & 28 & 56.00 \\
Crop production technology & 32 & 64.00 \\
Operation and maintenance of agricultural machines & 30 & 60.00 \\
\hline
\end{tabular}

Source: Ja'afar-Furo et al. (2011).

Note: There were multiple responses. 
Table 1 shows the various areas on which mid-career extension staff in the region needsto be trained. It could be seen from the table that, out of the eight areas identified in the assessment as needs for training, only two areas namely, crop production technology and livestock production and disease control pertain to production. The rest of the areas have to do with the activities other than production. This implies that farmers as well as the extension personnel were in need of knowledge on those areas but were not privileged to get adequate grasp of or access to such knowledge. Majority (96\%) need more knowledge on the marketing of agricultural commodities. Ja'afar-Furo et al.(2011) reported that in the survey they conducted among rural small-scale entrepreneurs in some parts of the region,, all the respondents cited inadequacy of markets for agricultural commodities, produce and products as a serious problem.Thus, the reason for such a high desire for knowledge in that area could mean that farmers have been incurring great losses of their agricultural produce, products and commodities because of either lack of markets or good feeder roads via which they can transport their commodities for sale. In such cases, they end up losing their produce due to spoilage as a result of poor, inadequate or even lack of storage facilities. This assertion particularly becomes very strong considering the fact that the results of the assessment as presented on Table 1show that $90 \%$ of organizations and stakeholders (farmers inclusive) indicated the need for training on storage and postharvest technology. Since, as said earlier, farmers have always been bothered with the need to increase production/yield, most of their activities are always geared towards increased production. This usually leads, accordingly, to increased output with no available means or innovations for storage of the surplus. Eventually, the smallholder farmers, who most oftensuffer from losses of enormous agricultural output, will end up being discouraged from even the production itself. This turns out to leave the farmers in poverty in the midst of riches.

The third highest $(78 \%)$ area of training needs is that of value addition on agricultural commodities. Value addition, which could be explained to mean the processes and activities to which agricultural commodities and products are subjected so that they will be preserved and have more value and longer shelf life, is another area that farmers need to use appropriate innovations. In the region assessed, due to improper or even in some cases the absence of value addition activities, most perishable agricultural commodities do not only attract low prices, but sometimes they are totally lost due to spoilage and deterioration.

The SAFE Programme Content and Adoption of Innovations by Smallholder Farmers: After the needs assessment which preceded the establishment of the SAFE Programme, the ADSU Faculty of Agriculture developed a curriculum which reflects a number of courses capable of imparting knowledge on innovative agricultural practices both to extension workers and smallholder farmers. The decision to include such modules was informed by the need to inculcate the practical knowledge and application of agricultural innovations to the potential graduates of the programme. This has a greater advantage vis-avis the already existing curriculum for the regular University undergraduate programme, which is largely based on theories. The graduates of SAFE are expected, after graduation, to go back to their smallholder farming communities and organizations and deliver same knowledge to smallholder farmers. Examples of the courses in the programme are:

Value Addition on Agricultural Products: This course providespractical innovative knowledge on preparation of animals for slaughter, evisceration and dressing percentage, care of carcass, processing and care of hides, skin and wool. Others are processing and storage of meat and milk. Milk hygiene, chemistry and nutritive value of meat and eggs are also taught in the course. Preparation and storage of beef products such as bacon, sausage and ham have also formed part of the value addition course that farmers need to know in order to get the best out of their animals and their products. On the part of plants, the biochemistry, physiology and the handling of fresh fruits and vegetables are being well taught.

Harvest and Postharvest Technology: Harvest and postharvest handling of farm produce have always been a serious problem to farmers. In view of this, the SAFE curriculum has made provision in the training modules to help farmers avoid or minimize the losses due to these. Fundamentals and principles of crop storage and transportation, storage and shelf life problems, ideal atmosphere for storing fruits, seeds, vegetables and other crop products form part of this course. Controlled environment for transit and long-term storage, protective treatment design and operation of equipment for storage and preservation, among others, are also taught to the potential extension graduates with the expectation that they will extend the knowledge to smallholder farmers. 
Agricultural Entrepreneurship: Agricultural activities are usually performed at subsistence levels among smallholder farming communities with the yields just as much as the households can eat, and sometimes even less than what a given household needs for consumption. However, the SAFE programme in ADSU has provided a lot of opportunities whereby farmers will operate beyond subsistence level $s$ to commercial levels through the use of innovations. This course is one of those that aim at enabling farmers to practice agriculture as a business. It is an in-depth business planning course. It covers evaluating resources, planning and research, legal and management issues, marketing strategies, budgets and financial statements. In the course, students are being trained to have good knowledge on agricultural entrepreneurship. The content covers, and not limited to, areas of farm diversification, marketing, agricultural product processing etc. At graduation, students are expected to have a complete business planning capacity.

Farm Business Management: Farm business management is another course that is included in the curriculum in order to capacitate the trainees in the process of decision-making. This comprises depreciation techniques and asset fixity, kinds and functions of farm records and accounts, nature of simple farm accounts etc.

Social Change and Rural Development: The course contents include, inert alia, concepts and theories of social change and their potential for modernization of rural societies; types of social change, factors causing resistance to change; change agent roles; facilitating collaboration and linkage between extension, research and smallholder farming community; identifying locally available resources such as human capacities, indigenous knowledge and locally produced technologies.

Experiences from the SAFE Programme in Adamawa State University: The SAFE programme in Adamawa State was started in 2011. Since then, there are a lot of experiences that have been recorded. Some of these are listed as follows:

i. In spite of the adverts made calling for applications for admission into the programme using various media (both electronic and print), only one application was received. In order to overcome that hurdle, the Head of Agricultural Economics and Extension and the SAFE Coordinator were sent on a sensitization tour to the six states of the north-east region. After the tour, 43 applications were received out of which 24 qualified and were admitted. This resulted into an additional cost besides the expenditure made in respect of the advertisements.

ii. It is required by SAFE that the organizations/employers where the midcareer agricultural extension staff would release their staff for training and sponsor them. However, despite the fact that many employershad consented to that condition, not even one of them have lived up to the promises/responsibilities.

iii. As an effort towards sustainability of the programme after SAFE withdraws counterpart funding, the students were asked to pay fees to the University. This became a serious problem because they were expecting to undergo the programme free and receive some allowances. Some of them threatened to withdraw though they admitted that they could benefit after graduation, but complained that they were finding it too difficult to meet the financial demands.

iv. The lecturers teaching SAFE programme courses, believing that the programme is an international lucrative programme dealing with dollars, expected extra pay apart from the salaries the university pays them. Lack of actualizing this ambition made some of them refuse to take part in teaching SAFE programme courses.

v. The facts that the students are adult learners married with children and havemany domestic responsibilities negatively affecting their concentration in learning as well as their percentage of attendance in lectures. They often take permission to travel for one reason or the other. This is seriously affecting the quality of learning they are expected to undergo.

Barriers to Effective Extension Services and their Implications for SAFE Programme: Despite the fact that SAFE programme in Adamawa State was established based on the results of the needs assessment, it is not without constraints and problems militating against it. There are two major sources of problems that the programme is faced 
with. One of the sources is the agricultural extension services agencies or organizations in the state. In Nigeria, the Agricultural Development Programme is the main organization which saddled with the responsibilities of delivering agricultural services to rural farmers. In the process of the needs assessment some of the major constraints found to affect the organizations where the SAFE programme students are working included unwillingness to release staff members due to inadequate funds meantfor staff training. This therefore, makes it difficult or even absolutely impossible for such experienced staff to be released for trainings such as the one of SAFE. Another barrier is the inability of the candidates to sponsor themselves due to the fact that their take-home salaries are grossly inadequate to carter for their dependants and the training at the same time. Most staff with a reservoir of knowledge and wealth of experiencethat could have been trained in the SAFE programme lacked motivation to engage in such full-time training programmes.

Implications of the Barriers to Effective Extension Services on SAFE Programme: If the programme is to be sustained and achieve its objectives, entrants must be holders of Higher National Diploma (HND) who are still working with various organizations. They must possess the required credits in relevant ordinary level subjects as required by the National Universities Commission (NUC).Smallholder farmers and smallholder farming in Adamawa State are greatly depending on the intervention of SAFE programme, among other change agencies and agents, for changes towards the use of innovations. This is apparent owing to the fact that the potential products of the programme are the ones who are expected to be in real contact with the farmers. Thus, since the Ministries of Agriculture and Higher Education have failed to carry out their responsibilities regarding staff training as evidenced from the SAFE programme is bound to be ineffective. This became obvious during the time admissions were to be given, when instead of a maximum of 40 students needed for the programme, only 25 were admitted. Taking into cognizance the geographical coverage of the NorthEast region where the SAFE graduates are expected to spread across, it will take many years for the impact of the programme to be felt. It, therefore, implies that the number of farmers to be reached with innovation packages in a given time is absolutely minimal.

The resultant effects of the constraints discussed are not only impeding the delivery of extension services in Nigeria, but also militating against the attainment of the achievements envisaged by the SAFE programme. This becomes apparent since, without further training, the extension staffs presently delivering extension services to smallholder farmers and rural communities cannot give information on recent improved farming practices and innovations which they themselves are not aware of. They lack the skills, knowledge, attitude and ability to deliver appropriate agricultural information and messages that farmers will use to enhance their production, productivity and other agricultural practices and activities. The capacity building which they really need to equip them to be capable carriers of the rich packages in the SAFE programme is grossly lacking. Likewise, smallholder farmers, the majority of who solely rely on the agricultural extension workers stationed in most rural areas have no option than to continue operating on subsistence levels. Thus, no matter how good the SAFE programme is planned, it is not going to succeed because it depends to a great extend on getting students from these organizations that are being confronted with manifold constraints.

\section{CONCLUSION}

The SAFE programme in Nigeria is achieving its set objective. It has the potential to reach more candidates and regions in the nation and other neighboring countries.

\section{RECOMMENDATIONS}

Based on the issues discussed, the following recommendations have been made:

i. The SAFE Foundation should endeavor to persuade and influence the Nigerian Government, especially the State Governments where SAFE programme is being run, to embark upon serious campaigns in order to create a wider awareness on the existence, relevance and benefits of the SAFE programme to farmers in particular and the nation in general.

ii. State and Local Governments, Ministries of Agriculture, Agricultural Development Programmes and other organizations, where agricultural extension and other agriculture-related mid-career staff are working, should be acquainted with the need for them to release their staff members to undergo the SAFE training programme. This will update their knowledge and prepare them for the new 
challenges aimed at ensuring food security in Nigeria.

iii. Nigerian Governments at various levels should review the bureaucratic bottlenecks that usually affect the release of funds meant for staff training both in terms of magnitude and timeliness.

iv. The universities running SAFE programme should design the training programme to give opportunity for parttime engagement in the training instead of only full-time programme.This will reduce the period within which prospective students would be absent from their homes and families.

\section{REFERENCES}

Njoku, E. C., M. and Adesope, C. O. N. (2007). Livelihood diversity strategies of rural women in Imo State, Nigeria. The Nigerian journal of agricultural extension
(10): 117-123. Published by Agricultural Extension Society of Nigeria (AESON).

Ekong, E. E. (2003). Rural Sociology: An introduction and analysis of rural Nigeria, Uyo: Dove Educational Publication, Nigeria.

Ja'afar-Furo, M. R., Bello, K. and Sulaiman, A. (2011). Assessment of the prospects of value addition among small-scale rural enterprises in Nigeria: Evidence from north-eastern Adamawa State.Journal of development and agricultural economics, 3(3): 144-149.

Ja'afar-Furo, M. R., Neils, J. S., Mojaba, D. I., Sulaiman, A. and Shall, J. D. (2012). Training needsassessment of mid-career agricultural extension officers: Evidences from Sasakawa Africa Fund for Extension Education (SAFE) intervention in North-east Nigeria. Journal of agricultural extension and rural development. Vol. 4(8), pp. 147-163.

World Bank (1996). "Nigeria: poverty in the most of plant. The challenges of growth with inclusion". A World Bank poverty assessment, Washington, D. C., World Bank. 